\title{
Nutritive value of multipurpose tree and shrubs fed to cattle and goats in the highland areas of Tanzania
}

\author{
MN Shem, AE Kimambo, BH Jumbe \\ Department of Animal Science and Production, Sokoine University of Agriculture, \\ PO Box 3004, Morogoro, Tanzania
}

\begin{abstract}
Samples of the different shrubs were collected from five districts in Kilimanjaro in Northern region from June 1988 to may 1989 . Five bulk samples for each trees or shrub leaves were collected. Each bulk sample was obtained by mixing 20 samples of the tree or shrub leaves collected throughout the study period. The samples included those collected both during the wet and dry seasons.
\end{abstract}

The samples were analyzed according to AOAC (1980, Official methods of analysis, Washington DC) methods for dry matter (DM) and organic matter (OM). Crude protein (CP) for nitrogen $(\mathrm{N})$ determination was analyzed by the Kjeldal method using a semi-automated $\mathrm{N}$ analyzer. Dry matter degradation DMD from nylon bags was determined according to the model described by Ørskov et al (1980, Trop Anim Prod, 5, 195-213). The data was then fitted to the mathematical model $p=a+b\left(1-e^{-c t}\right)$ (McDonald, 1981, J Agric Sci, $96,251-252)$ where $p$ is the percent degradation at time $t$; $a$ is the zero time intercept, $b$ is the degradation constant, $a+b$ is the potential degradability and $c$ is the degradation rate constant. ME values were estimated from $48 \mathrm{~h}$ dry matter degradability (DMD 48).

\begin{tabular}{|c|c|c|c|}
\hline Feed & $\begin{array}{l}\text { DM } \\
\mathrm{g} / \mathrm{kg}\end{array}$ & $\begin{array}{l}\mathrm{CP} \\
\mathrm{g} / \mathrm{kg}\end{array}$ & $\begin{array}{c}\text { DMD } 48 \mathrm{~h} \\
\mathrm{~g} / \mathrm{kg} \mathrm{DM}\end{array}$ \\
\hline G. robusta & 420 & 92 & 486 \\
\hline Cor. holstii & 254 & 221 & 507 \\
\hline D.afromontana & 213 & 170 & 601 \\
\hline Albizia spp. & 372 & 213 & 466 \\
\hline T.orentalis & 389 & 180 & 471 \\
\hline B.micrantha & 370 & 177 & 466 \\
\hline M.kimandscharica & 383 & 142 & 620 \\
\hline C.holstii & 297 & 154 & 869 \\
\hline P.americana & 410 & 125 & 502 \\
\hline E.japonica & 436 & 104 & 597 \\
\hline C. macrostachyus & 204 & 250 & 621 \\
\hline C.zimmermanni & 335 & 131 & 498 \\
\hline$M$. discoides & 353 & 229 & 804 \\
\hline I.mitis & 459 & 129 & 780 \\
\hline SED & 8.7 & 3.8 & 11.5 \\
\hline $\mathrm{F}$ ratio & $\star \star \star \star$ & $\star \star \star$ & 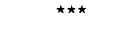 \\
\hline
\end{tabular}

Chemical analyses and in sacco degradability studies showed highly significant differences $(P<0.05)$ in chemical composition and degradability constants. Dry matter (DM) values for the shrub and tree leaves significantly $(P<0.05)$ varied between species, ranging from as low as $204 \mathrm{~g} / \mathrm{kg}$ in $C$. Macrostachyus to $459 \mathrm{~g} / \mathrm{kg}$ in I.mitis. Crude protein (CP) contents varied significantly $(P<0.05)$ with value ranging from $92 \mathrm{~g} / \mathrm{kg}$ to $250 \mathrm{~g} / \mathrm{kg}$ on DM basis for G.robusta and C.macrostachyus respectively. DM degradability at 48 hours and the estimated ME values also varied significantly $(P<0.05)$ between shrubs ranging from 6.5 ME MJ/kg DM for Albizia spp and B.micrantha respectively to 12.9 ME MJ/kg DM for C. holstii. The potential degradability $(A+B)$ varied significantly $(P<0.05)$ between shrubs, ranging from 522 $\mathrm{g} / \mathrm{kg}$ DM to $904 \mathrm{~g} / \mathrm{kg}$ for Albizia spp and C.holstii respectively. The degradation rate constant $(c)$ also varied significantly $(P<0.05)$ between shrubs. It ranged from 0.0278 for $T$. orientalis to 0.0584 for $C$. holstii.

It can be concluded that locally available tree and shrub leaves had high nutritive values than crop residues like maize stover especially in terms of $\mathrm{N}$.

ME was estimated from DMD 48.

\begin{tabular}{|c|c|c|}
\hline $\begin{array}{c}\text { ME MJ/ } \\
\text { kg DM }\end{array}$ & $\begin{array}{c}a+b \\
g / k g ~ D M\end{array}$ & $\begin{array}{c}\mathrm{c} \\
\mathrm{h}\end{array}$ \\
\hline 6.9 & 538 & 0.0474 \\
\hline 7.2 & 597 & 0.0360 \\
\hline 8.7 & 690 & 0.0455 \\
\hline 6.5 & 522 & 0.0463 \\
\hline 6.6 & 580 & 0.0278 \\
\hline 6.5 & 566 & 0.0306 \\
\hline 8.9 & 706 & 0.0410 \\
\hline 12.9 & 904 & 0.0584 \\
\hline 7.1 & 541 & 0.0511 \\
\hline 8.6 & 685 & 0.0352 \\
\hline 8.9 & 722 & 0.0318 \\
\hline 7.0 & 563 & 0.0444 \\
\hline 11.8 & 851 & 0.0516 \\
\hline 11.5 & 839 & 0.0504 \\
\hline 0.3 & 4.00 & 0.0099 \\
\hline 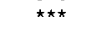 & . & 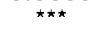 \\
\hline
\end{tabular}

